\title{
Histopathological Effects and Element Concentration Of Body Tissues Of Ranid Frog Inhabiting Polluted Water Sites
}

\begin{abstract}
Aqeela Zahra
Muhammad Tayyab

Irfan Zia Qureshi

School of Psychology, South China Normal University, Shipai, Tianhe District, Guangzhou, China

doi: 10.19044/esj.2016.v12n8p388 URL:http://dx.doi.org/10.19044/esj.2016.v12n8p388

Abstract

Freshwater or wetlands are being polluted on regular basis due to the release of domestic sewage and most importantly industrial effluents that include chemicals, organic pollutants and heavy metals, and run-off from land-based activities containing leached fertilizers. Pollutants are such substances that reduce quality of water that effect directly and indirectly. The present study was carried out on Korang River Islamabad/Rawalpindi. Two different locations were selected along the Korang River. The data were collected two times during the current study period; March 2012, and October 2012. Ranid frogs $(n=10)$ were captured from all selected sites, which were dissected to collect blood and body tissue samples. During the month of March and October the concentration of heavy metals in water samples increase and decrease significantly at both sites of Korang River. The continuous leaching of contaminants may cause abnormal tissue damage in amphibians making them more vulnerable to predation and competition and also decreased reproductive success.
\end{abstract}

Keywords: Rana clamitans; Atomic absorption spectrophotometer; Korang River

\section{Introduction}

Freshwater or wetlands are being polluted on regular basis due to the release of domestic sewage and most importantly industrial effluents that include chemicals, organic pollutants and heavy metals, and run-off from land-based activities containing leached fertilizers. The disturbance caused by humans in the environment has directly affected are amphibian population and their extinction by depletion of Ozone layer that correlates to the 
mortality of amphibians egg, habitat destruction and fragmentation are also accepted that causes local extinctions. Pollutants are such substances that reduce quality of water. That may or may not result from human activity. Main sources of pollution are oil spills or radioactivity from the atmosphere or antifouling paints. Pollutants have ability to dissolve in water or adhere to the particles, or exist as particles, float, or can be sediment in the bottom (Chapman, 1995). Almost 50\% of the total pollution is caused by the surface water due to the presence of ammonium ion $\left(\mathrm{NH}_{4}\right)$ and $\mathrm{NO}_{3}$ obtained from agricultural inputs. Wastes, manures and sludge's, through biological concentration processes, can supply soils with hundred times more dangerous products than do fertilizers for the equivalent plant nutrient content (Joly, 1993). Pathogens are organic substances, heavy metals and trace elements are major polluting agents and direct and indirect threat to ecosystems and organisms. Sewage is primarily organic in nature and is therefore, degraded by bacterial decay. Due to the bacterial action biological oxygen demand (BOD) increases because of reduced concentration of oxygen in water that result in depletion of oxygen to aquatic life that leads to the breakdown of proteins and releasing hydrogen sulphide and ammonia, both of which are potentially toxic to marine organisms in low concentrations that are harmful to marine life even in low concentration (Duursma and Marchand, 1974).

When pollutants are released into aquatic habitats, direct toxic effects on aquatic biota are most likely to occur. Direct effects vary with the intensity and duration of exposure to a toxicant, and based on species responses to contaminants. The direct effects of toxicants typically reduce organism abundance through increased mortality or reduced by means of fecundity. Direct sub lethal effects, such as behavioral impairment or physiological stress, are also possible (Long et al., 1995). Pollutants effect also occurs indirectly through a number of biological mechanisms that are also known as secondary contaminants effects. Such effects can be determined by studying the pollutant effect at population or ecosystem level rather than at single species or laboratory base toxicity level. However secondary contaminant effect also occur directly on predators and grazers which then leads to indirect effect on trophic level (Cairns, 1983; Clements and Kiffney,1994). There are many substances that act as pollutants and reduce water quality. They are divided into six groups like inorganic pollutants, pathogens, cations (nitrates, phosphate, sulphates, $\mathrm{Ca}^{2}{ }^{2}, \mathrm{Mg}^{2}$ and $\mathrm{F}^{-1}$ ), anions and also some organic compounds. These substances are known to disrupt the ecosystem. Their quality increases its threshold value and also adversely effect on human health. In Pakistan iron, arsenic, cadmium, nickel and pesticides are major metals that are badly affecting the water quality. As regards the hydrological cycle a number of trace elements 
are being added to natural water during moving downward. These heavy metals produce adverse effects on the ecosystem life and human health. WHO reported that the concentration of these toxic metals in Pakistan's ground water has reached its maximal value. One possible mechanism that world allow for temperature compensation in anurans is physiological function of acclimatization. Acclamatory responses are shown by tadpoles from species with terrestrial adults (Wilson and Franklin, 1999) and both tadpoles and adults of a fully aquatic species (Wilson and Franklin, 2000) that improve swimming at low temperature (Watkins and Vraspir, 2006). Additionally, post-hatching temperatures affect both morphology and swimming performance in tadpoles. (Figure 1)

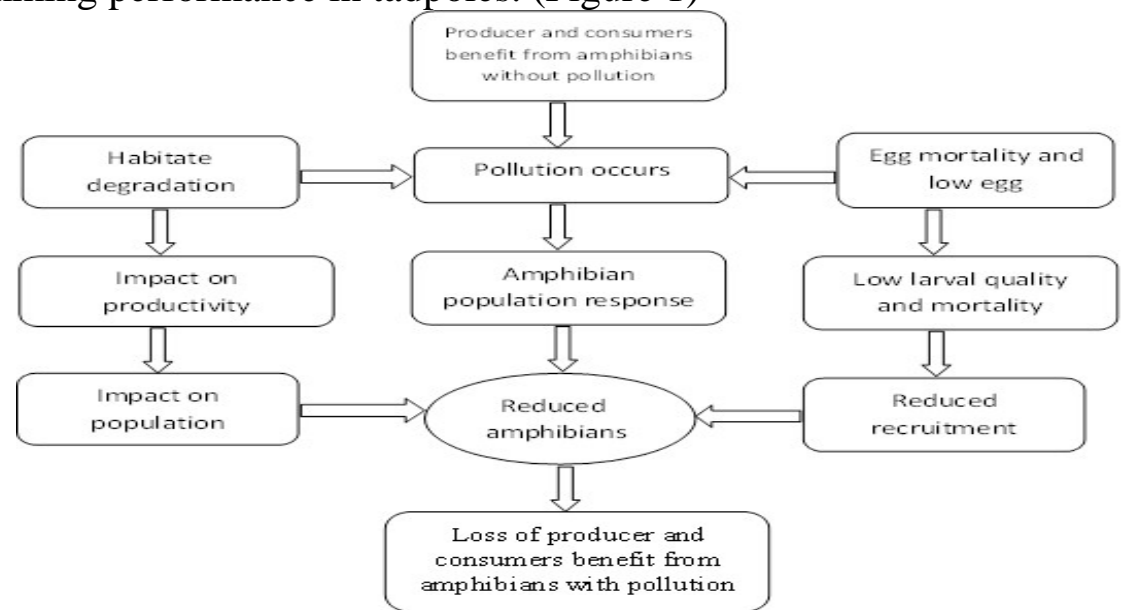

Figure 1: Generalized scheme showing effects of pollution on amphibian population

However, acclimation does not seem to affect the locomotors performance of terrestrial adult anurans (Rome et al., 1992), perhaps because the thermally variable terrestrial environments do not provide stable cues (Wilson and Franklin, 2000).Research in the conservation of amphibians has grown exponentially within the past two decades. The described amphibians species are threatened with extinction are $32 \%$ and $43 \%$ of the population are declining (IUCN, 2008). However, in addition, the cause of over half of all decreases in amphibian populations is unidentified (Stuart et al., 2004). Loss of habitat affects loss of species in terrestrial ecosystems more than any other factor (Sala et al., 2000). An emerging infectious disease of amphibians chytridiomycosis (the amphibian chytrid) (Berger et al., 1998; Nichols et al., 1998) has resulted in considerable research on this disease (Daszak et al., 1999). The amphibian population has received increased attention because of the possible interaction between climate changes and disease outbreak. (Pounds et al., 2006; Rohr et al., 2008). Through several mechanism the environmental variation and how individual are exposed to the variation could modify the disease risk (Anderson and May, 1978), changing 
community structure (Poteet, 2006;) affecting the condition of hosts or pathogens (Jokela et al., 2005; Jolles et al., 2005). By increasing the density of host and subsequent transmission rates. The effect of disease by disturbance for example fragmentation or unusal climate events can be modified (Lafferty and Holt, 2003).

\section{Materials and Methods}

Study Area:

The present study was carried out on Korang River Islamabad/Rawalpindi. The river starts from Rawal Lake Islamabad, and after covering a distance of about 20 kilometers waterfall into Sowaan River in Rawalpindi. The destiny of the river depends upon the opening and closing of the spillways of the Rawal Lake, Islamabad as during the rainy season the lake gets filled up with water and the spillways are opened to control the level of water in the lake. The river water gets polluted due to drains entering into the river from the surrounding areas on either sides of the river in Islamabad and Rawalpindi which go down in the Korang River.

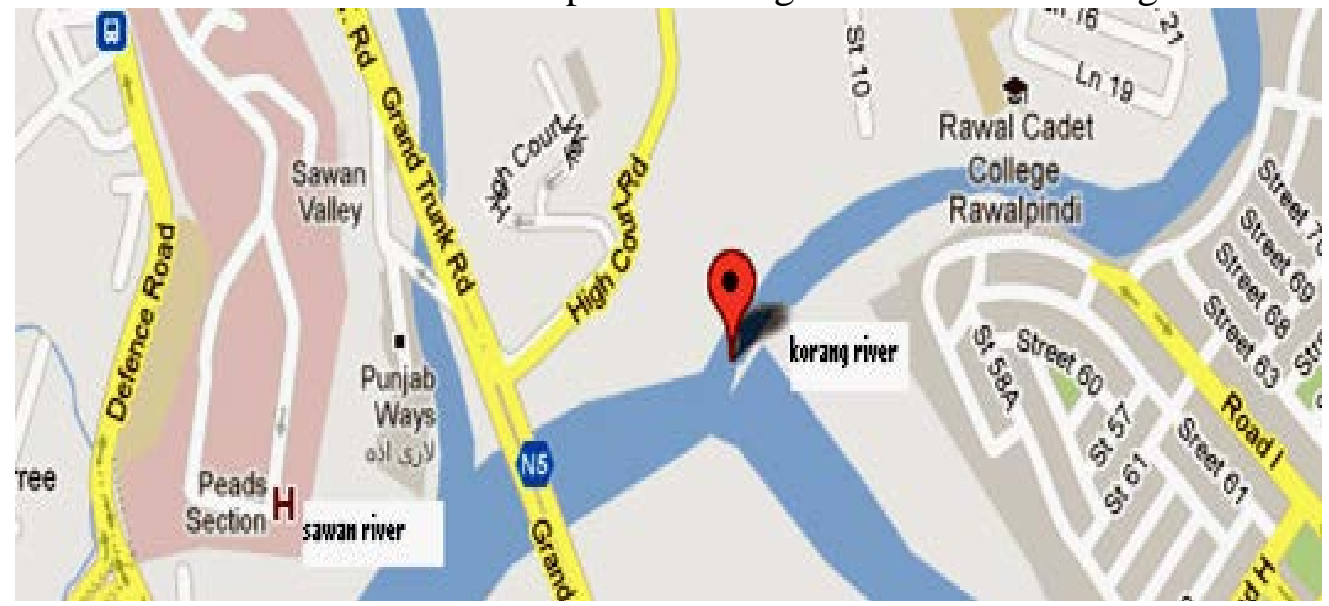

Figure 2: Geographical map of Korang River

\section{Study design}

Control frog samples were captured from non-polluted sites of suburban ponds atleast 5 kilometers away from polluted site. Two different locations were selected along the Korang River. Each site consisted of one kilometer long belt of the river with variable width. The observations and data were collected from both the sides across the river. Sites were selected on the basis of pollution in water evident through water color and appearance. The data were collected two times during the current study period; March 2015, and October 2015. During data collection, water samples $(n=6)$ were taken from each study site. Ranid frogs $(n=10)$ were captured from all selected sites, which were dissected to collect blood and 
body tissue samples. Control samples of frog tissues were taken from the Quaid-e-Azam University, Islamabad during the same time period. Concentrations of a range of heavy metals were estimated in blood samples (collected from selected frogs), water samples and also in body tissues of frogs (captured from study sites). The water samples were also collected from the control area for estimation of the heavy metals concentrations using atomic absorption spectrophotometer. For investigating any damage caused at the tissue level, tissue from the captured frogs were fixed in $10 \%$ formalin solution and processed for staining, dehydration and embedding in paraffin wax. Microscopic sections of the testes, ovaries, kidney and liver were prepared.

\section{Results}

Heavy metal concentrations were investigated from water samples and tissue samples of frog (Rana clamitans) that are collected from two different sites of Korang River. Water samples were collected from two different sites of Korang River during the month of March 2012 and October 2012. During the month of March (Table 1) the concentration of zinc, cadmium, lead and iron in water samples from both site 1 and site 2 were found not high as compared to control at both site 1 and site 2 but the concentration of manganese was slightly elevated at site $2(0.065 \pm$ $0.017 \mu \mathrm{g} / \mathrm{ml})$ as compared to control $(0.037 \pm 0.007 \mu \mathrm{g} / \mathrm{ml})$. The concentration of manganese in water sample from site 2 was nonsignificantly $(p<0.052)$ elevated than the control during March .The concentration of nickel could not be detected at both sites. During the month of October (Table 2) concentration of cadmium and iron in water samples from site 1 and site 2 were found not higher than the control, but the concentration zinc and lead were slightly elevated at both sites 1(0.185 \pm $0.021),(0.17 \pm 0.015)$ and site $2(0.047 \pm 0.0065),(0.025 \pm 0.0063)$ as compared to control $(0.125 \pm 0.011)$.

Table 1: Heavy metals concentration $((\mu \mathrm{g} / \mathrm{ml})$ in water samples during March sample size is

\begin{tabular}{|c|c|c|c|c|}
\hline METAL & CONTROL & SITE I & SITE II & T-TEST \\
\hline $\mathbf{Z n}$ & $0.22 \pm 0.027$ & $0.056 \pm 0.009$ & $\begin{array}{c}0.037 \pm \\
0.003\end{array}$ & $\begin{array}{c}\text { (t } 1.795(10) ; \mathrm{p}<0.103 ; 95 \% \mathrm{CI}:- \\
0.00455 \text { to } 0.04221)\end{array}$ \\
\hline Cd & $0.017 \pm 0.001$ & $0.008 \pm 0.002$ & $\begin{array}{c}0.010 \pm \\
0.003\end{array}$ & $\begin{array}{c}\text { (t } 0.890(10) ; \mathrm{p}<0.394 ; 95 \% \text { CI :- } \\
0.0526 \text { to } 0.01226)\end{array}$ \\
\hline $\mathrm{Cr}$ & ND & $0.128 \pm 0.037$ & $\begin{array}{c}0.163 \pm \\
0.038\end{array}$ & $\begin{array}{c}\text { t } 0.804(10) ; \mathrm{p}<0.440 ; 95 \% \text { CI :- } \\
0.08264 \text { to } 0.17598)\end{array}$ \\
\hline Mn & $0.037 \pm 0.007$ & $0.011 \pm 0.002$ & $\begin{array}{c}0.065 \pm \\
0.017\end{array}$ & $\begin{array}{c}(\mathrm{t}-2.505(5.22) ; \mathrm{p}<0.052 ; 95 \% \mathrm{CI} \\
:-0.09831 \text { to } 0.00065)\end{array}$ \\
\hline $\mathbf{F e}$ & ND & $0.066 \pm 0.014$ & $\begin{array}{c}0.008 \pm \\
0.00\end{array}$ & $\begin{array}{c}\text { (t 2.367(5.05); } \mathrm{p}<0.064 ; 95 \% \text { CI :- } \\
0.00356 \text { to }-.089)\end{array}$ \\
\hline $\mathbf{P b}$ & $0.085 \pm 0.023$ & $\begin{array}{c}0.005 \\
\pm 0.00024\end{array}$ & $\begin{array}{c}0.005 \pm \\
0.00\end{array}$ & $\begin{array}{c}(\mathrm{t}-1.000(5.00) ; \mathrm{p}<0.363 ; 95 \% \mathrm{CI} \\
:-0.00357 \text { to } 0.00157)\end{array}$ \\
\hline
\end{tabular}


Table 2: Heavy metals concentration $((\mu \mathrm{g} / \mathrm{ml})$ in water samples during October sample size is $n=6$

\begin{tabular}{|c|c|c|c|c|}
\hline METAL & CONTROL & SITE I & SITE II & T-TEST \\
\hline Zn & $0.125 \pm 0.011$ & $\begin{array}{c}0.185 \pm \\
0.021 \\
\end{array}$ & $\begin{array}{c}0.037 \pm \\
0.003 \\
\end{array}$ & $\begin{array}{c}(\mathrm{t}-0.47(10) ; \mathrm{p}<0.644 ; 95 \% \mathrm{CI} \\
:-0.12474 \text { to } 0.08074)\end{array}$ \\
\hline Cd & $0.015 \pm 0.008$ & $\begin{array}{l}0.012 \pm \\
0.0026 \\
\end{array}$ & $\begin{array}{c}0.010 \pm \\
0.003 \\
\end{array}$ & $\begin{array}{c}\text { (t 3.049(5.430); } \mathrm{p}<0.026 * ; 95 \% \\
\text { CI :-0.00177 to } 0.01823)\end{array}$ \\
\hline $\mathrm{Cr}$ & ND & $0.059 \pm 0$ & $\begin{array}{c}0.163 \pm \\
0.038 \\
\end{array}$ & $\begin{array}{c}\text { (t 1.000(5.00); } \mathrm{p}<0.363 ; 95 \% \\
\text { CI :-0.02225 to } 0.05058)\end{array}$ \\
\hline Mn & $0.011 \pm 0.003$ & $\begin{array}{l}0.047 \pm \\
0.0065 \\
\end{array}$ & $\begin{array}{c}0.065 \pm \\
0.017 \\
\end{array}$ & $\begin{array}{c}\text { (t } 0.342(10) ; \mathrm{p}<0.739 ; 95 \% \mathrm{CI} \\
\quad:-0.02390 \text { to } 0.03257)\end{array}$ \\
\hline $\mathbf{F e}$ & $0.075 \pm 0.023$ & $\begin{array}{c}0.067 \pm \\
0.010\end{array}$ & $0.06 \pm 0$ & $\begin{array}{c}\text { (t } 0.409(10) ; \mathrm{p}<0.691 ; 95 \% \text { CI } \\
:-0.02743 \text { to } 0.03976)\end{array}$ \\
\hline $\mathbf{P b}$ & ND & $\begin{array}{l}0.017 \pm \\
0.015 \\
\end{array}$ & $\begin{array}{c}0.048 \pm \\
0.011 \\
\end{array}$ & $\begin{array}{c}(\mathrm{t}-0.871(10) ; \mathrm{p}<0.044 ; 95 \% \mathrm{CI} \\
:-0.05930 \text { to } 0202596) \\
\end{array}$ \\
\hline $\mathbf{N i}$ & $\mathrm{ND}$ & $\begin{array}{l}0.025 \pm \\
0.0063\end{array}$ & $\begin{array}{l}0.043 \pm \\
0.0055\end{array}$ & $\begin{array}{c}(\mathrm{t}-1.533(6.542) ; \mathrm{p}<0.172 ; 95 \% \\
\mathrm{CI}:-0.04360 \text { to } 0.00960)\end{array}$ \\
\hline
\end{tabular}

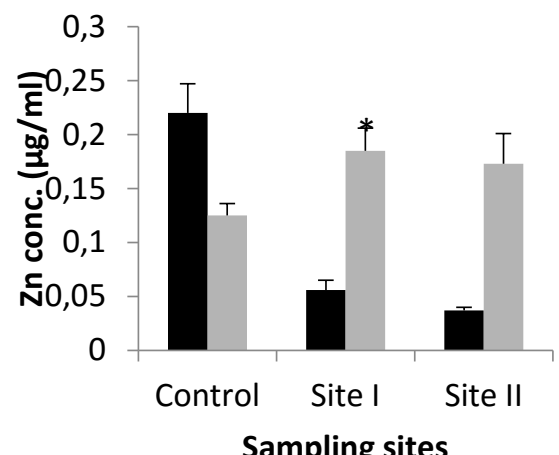

Sampling sites

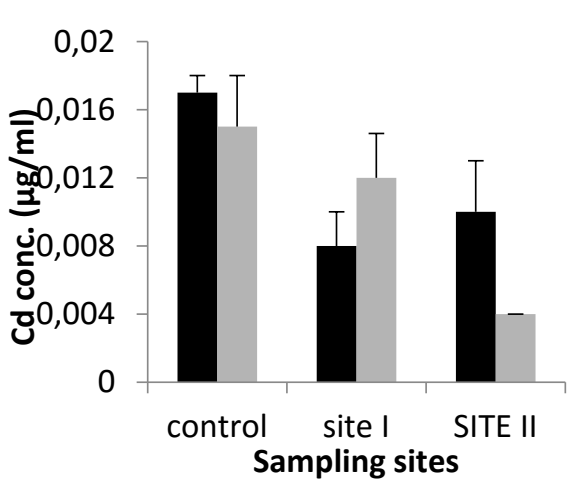

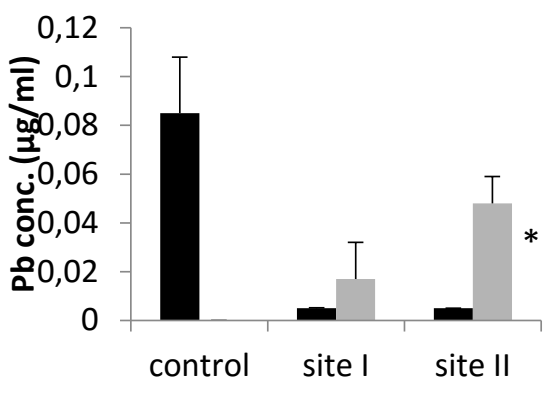

Sampling sites

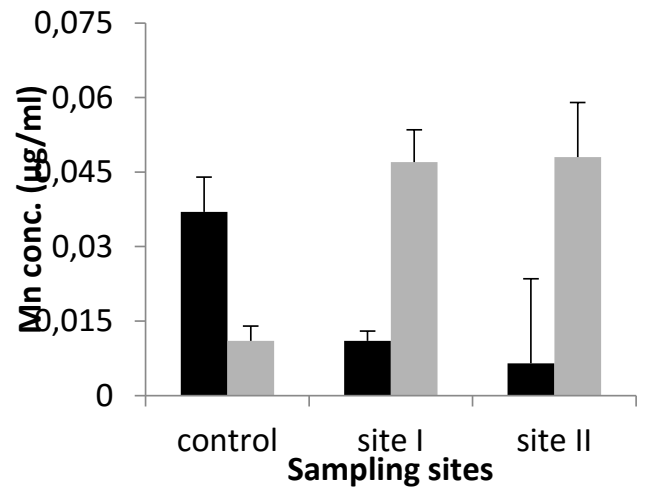




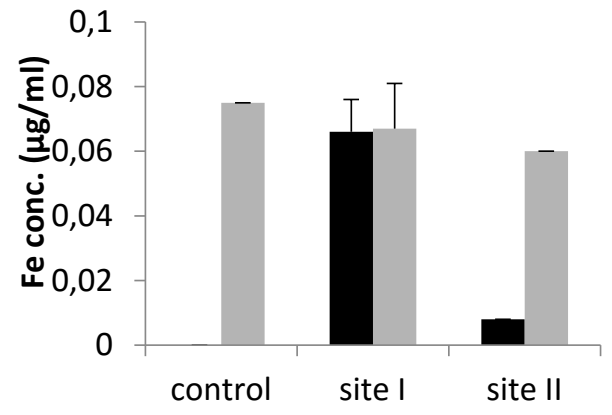

Sampling sites

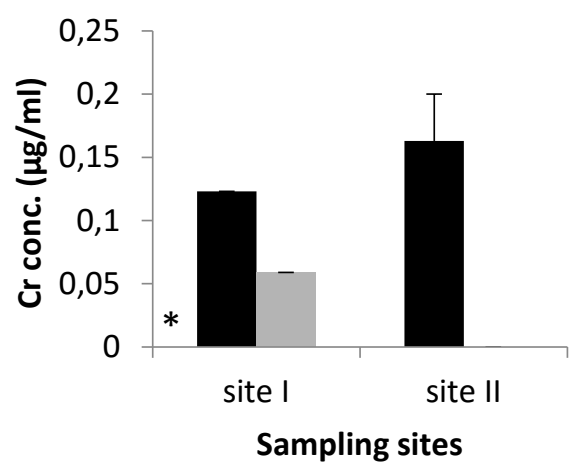

Figure 3: Comparison of $\mathrm{Zn}, \mathrm{Pb}, \mathrm{Cd}, \mathrm{Mn}, \mathrm{Fe}$, and $\mathrm{Cr}(\mu \mathrm{g} / \mathrm{ml})$ concentration of control water samples with site 1 and 2 samples. * Shows significant difference in concentration at site II in March to that in October at $\mathrm{p}<0.05$.

Heavy metal concentrations in various bodily tissue samples of Ranid frogs (heart, stomach, muscle) were estimated at two selected sites. (Figure 4) The heart tissues from site 1 showed elevated concentration of $\mathrm{Pb}$ (0.405 \pm 0.095$)$, Mn $(0.435 \pm 0.111)$ and Fe $(520.9 \pm 120.0)$ as compared to control. The concentrations of $\mathrm{Zn}(2.685 \pm 1.030)$, and Fe (590 \pm 145.7$)$ in the stomach samples of frogs were found elevated level than control samples at site 1. At study site $2 \mathrm{Zn}(2.152 \pm 0.640)$ and Mn (0.420 \pm 0.135$)$ showed increased concentration in stomach of frog as compared to those of control samples. Concentration of $\mathrm{Cd}$ and $\mathrm{Pb}$ remain less in site 1 and 2 then control samples. Samples of muscles from frog of site 1 showed elevated concentration of $\mathrm{Pb}(0.501 \pm 0.164), \mathrm{Mn}(0.590 \pm 0.125)$ and $\mathrm{Fe}(505.1 \pm 131.5)$ in comparison to those of control. However frog muscle samples of site 2 showed increase concentration of fe(218. \pm 63.00$)$ then the control muscle samples. Concentration of $\mathrm{Zn}$ and $\mathrm{Cd}$ give no elevation to control muscle samples. (Table 3,4,5). Histological studies of the control section of (1) heart, (2) stomach, (3) muscle, (4) kidney, (5) liver, (6) ovary tissues of frog (Rana clamitans) showed normal appearance while, it showed great disruption in the animal tissue taken from both study sites (Figure 5).

Table 3: Conc. of heavy metals $(\mu \mathrm{g} / \mathrm{ml})$ in specimen's heart collected from control site-I \& site-II

\begin{tabular}{|c|c|c|c|}
\hline METAL & SITE I & SITE II & CONTROL \\
\hline Zn & $1.02 \pm 0.33$ & $1.32 \pm 0.66$ & $1.16 \pm 0.65$ \\
\hline Cd & $0.007 \pm 0.00$ & $0.01 \pm 0.002$ & $0.04 \pm 0.01$ \\
\hline Pb & $0.40 \pm 0.09$ & $0.54 \pm 0.11$ & $0.25 \pm 1.06$ \\
\hline Mn & $0.43 \pm 0.11$ & $0.46 \pm 0.126$ & $0.13 \pm 0.046$ \\
\hline Fe & $520.9 \pm 120$ & $230.9 \pm 75.35$ & $22.8 \pm 10.9$ \\
\hline
\end{tabular}


Table 4: Conc. of heavy metals $(\mu \mathrm{g} / \mathrm{ml})$ in specimen's stomach collected from control site-I \& site-II

\begin{tabular}{|c|c|c|c|}
\hline METAL & SITE I & SITE II & CONTROL \\
\hline Zn & $2.68 \pm 1.03$ & $2.15 \pm 0.64$ & $1.54 \pm 0.76$ \\
\hline Cd & $0.01 \pm 0.002$ & $0.05 \pm 0.007$ & $0.04 \pm 0.01$ \\
\hline Pb & $0.30 \pm 0.04$ & $0.71 \pm 0.16$ & $1.36 \pm 0.41$ \\
\hline Mn & $0.24 \pm 0.06$ & $0.42 \pm 0.13$ & $0.19 \pm 0.03$ \\
\hline Fe & $590 \pm 145.7$ & $306.8 \pm 95.15$ & $17.0 \pm 5.90$ \\
\hline
\end{tabular}

Table 5: Conc. of heavy metals $(\mu \mathrm{g} / \mathrm{ml})$ in specimen’s muscles collected from control site-I

\begin{tabular}{|c|c|c|c|}
\hline \multicolumn{4}{|c|}{ \& site-II } \\
\hline METAL & SITE I & SITE II & CONTROL \\
\hline Zn & $0.46 \pm 0.06$ & $1.15 \pm 0.87$ & $1.46 \pm 0.70$ \\
\hline Cd & $0.01 \pm 0.002$ & $0.008 \pm 0.001$ & $0.03 \pm 0.007$ \\
\hline Pb & $0.43 \pm 0.10$ & $0.39 \pm 0.09$ & $0.50 \pm 0.16$ \\
\hline Mn & $0.59 \pm 0.12$ & $0.46 \pm 0.041$ & $0.14 \pm 0.02$ \\
\hline Fe & $505.1 \pm 131.5$ & $218 . \pm 63.0$ & $42.41 \pm 8.01$ \\
\hline
\end{tabular}

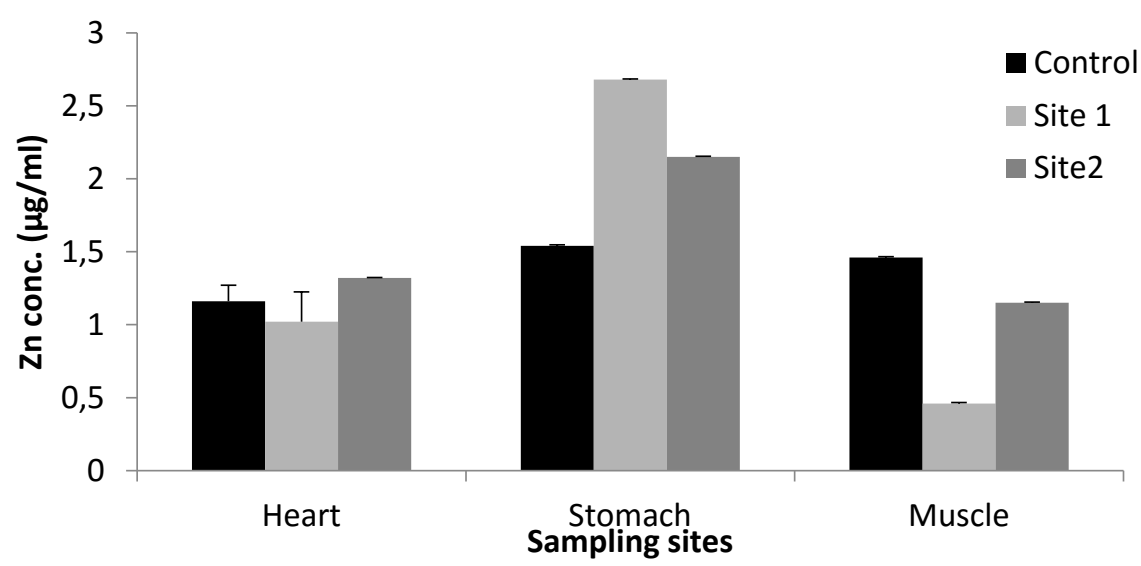

Figure 4: Heavy metal concentrations in body tissues of frogs (heart, stomach, muscle) were estimated at two selected sites. 


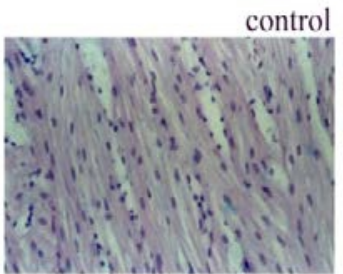

site 1

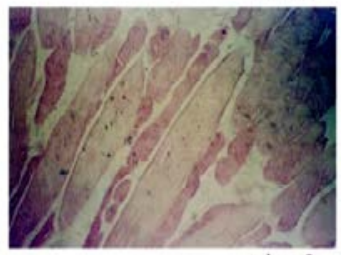

site 2

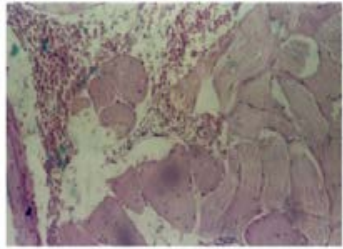

1

2

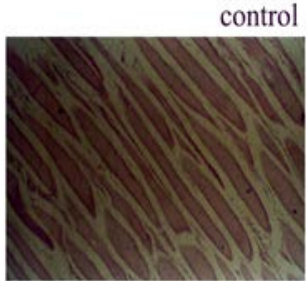

site 1

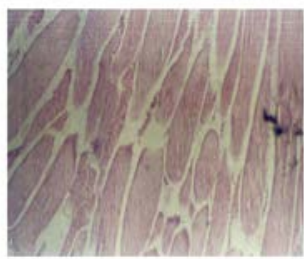

site 2

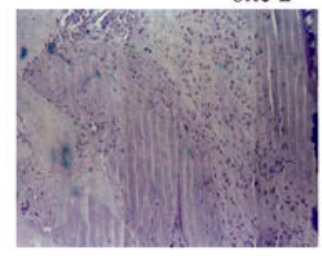

control

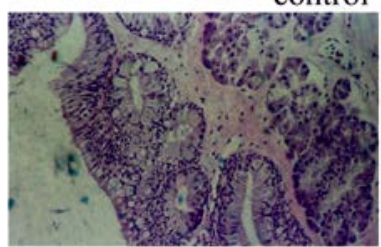

site 1

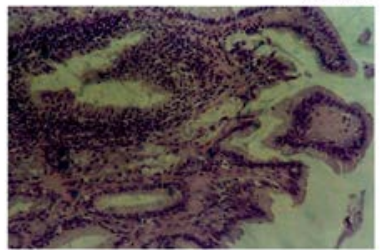

site 2

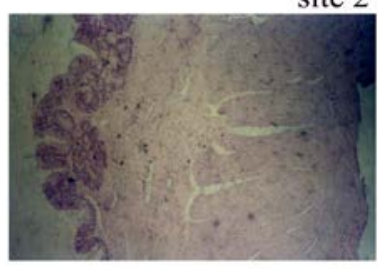

3

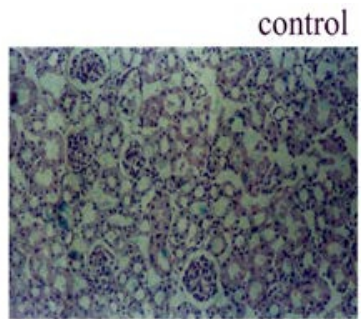

site 1

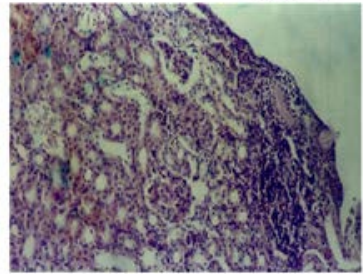

site 2

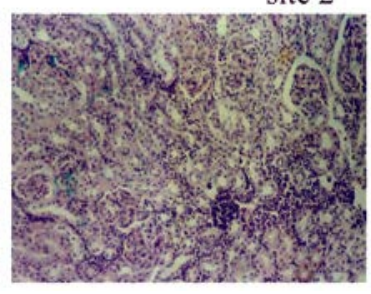

4

Figure 5: Photomicrograph of (1) heart, (2) stomach, (3) muscle, (4) kidney, (5) liver, (6) ovary tissues of frog (Rana clamitans) from site 1 and 2 in comparison with control. 


\section{Discussion}

Water contamination is one of the main causes of physiological problems in human beings and other living organisms. Contaminants in aquatic ecosystems are clearly capable of causing a range of indirect biological effects that can be as or more significant than the direct (toxic) effects of a contaminant. Amphibians are much more responsive to the chemical contaminants. About $70 \%$ of the amphibian populations have declined. According to the IUCN Red List (2004), there are 20 countries with highest number of threatened amphibians. One of the most vulnerable groups of animals in this respect is amphibians, and especially frogs, since they totally depend upon water for their reproduction. In the current study, concentrations of some heavy metals including zinc, cadmium, lead, manganese and iron were assessed in river water samples, blood samples, and also in the heart, muscle, stomach, liver, kidney and gonads of Ranid frogs inhabiting the Korang river of Islamabad. Except zinc which was found in greater concentration in the stomach tissue samples of frogs from all sites. The water samples from the three selected sites showed elevated levels of certain metals indicating heavy metals in the study river. Heavy metals like zinc $(\mathrm{Zn})$, lead $(\mathrm{Pb})$, cadmium $(\mathrm{Cd})$, manganese $(\mathrm{Mn})$, may badly influence the amphibian populations (Blaustein et al., 2003). In the current study, the concentrations of $\mathrm{Mn}$ and Fe were found elevated in tissue samples of frogs from both of the selected sites. This is in accordance with the elevated levels of these two metals in water samples of the sites. It showed that frogs acquired these two metals from the river water leading to elevation in blood levels. Similarly, Zn levels were also found elevated in tissue samples of frogs from the two sites. The deposition of various metals at the tissue level is of greater concern. The same two metals, that is, Mn and Fe, were found to have higher levels in the heart, stomach and muscle tissues of frogs collected from the two sites. The bodily tissues of frogs perhaps acquired $\mathrm{Mn}$ and Fe from the blood. Similarly, levels of Zinc were found elevated in the stomach samples of frogs from study site II. Some earlier studies do support the findings of the current study, for example, concentrations of fourteen different heavy metals were found evaluated in various tissues of the frog Rana ridibunda, inhabiting the river of Macedonia (northern Greece). Among various tissues, liver contained significantly greater amounts of copper, cobalt, molybdenum, chromium, and cadmium. Zinc was found to be acutely and chronically toxic to the aquatic organisms. Zinc is known to be bio-accumulated, and the concentration factors of the zinc for Cladophora glomerata from the lake Ontario were found to be 2900 and 1000.

In the current study, heart, stomach and muscle tissues were found to be having some cellular abnormalities. Abnormal cells in these tissues were irregularly shaped and contained depositions. The metal deposition in the 
muscles may lead to mononuclear infiltration, sarcolemma disruption and shows tissue congestion. The metal deposition in the ovaries may lead to malfunctioning of reproductive system showing abnormal follicles and cytoplasm regression with reduced reproductive output, causing decline in the population of the animal species. The most common frogs inhabiting suburban areas were more likely to suffer from reproductive abnormalities than those inhabiting rural areas. He found more than $20 \%$ of male green frogs (Rana clamitans) from suburban Connecticut ponds as hermaphrodites, having immature eggs in their testes. Frogs inhabiting polluted water may suffer from reproductive abnormalities.

A few physical deformities were also observed in frogs captured from the study sites such as, larger and smaller limbs, lethargic behavior, lighten skin color, more waxy material on the skin, twisted bones of their limbs and less active. The published literature shows that frogs and their larvae show various deformities after being exposed to teratogenic contaminants like radio chemicals and heavy metals.

\section{Conclusion}

All these abnormalities may make amphibians more vulnerable to predation and competition and also decreased reproductive success. The disturbance caused by humans in the environment has directly affected are amphibian population and also different kinds of pollutants, especially heavy metals in polluted water may have toxic effects on the various body tissues of animals inhabiting the polluted water sites. Coastal areas of the world are badly affected by the pollution that causes damage to commercial coastal and marine fisheries so it is essential to control the pollution for the conservation of the existing fisheries and aquatic resources. Unfortunately, there are many problems that make it difficult to control the pollution, are characterized by interconnectedness, complicated interactions, conflicts and constraints. These can also affect several bodily functions like general body metabolism, hormonal control, and growth. The continuous leaching of contaminants causes abnormal tissue damage in amphibians.

\section{References:}

Anderson, R.M., May, R.M., (1978). Regulation and stability of hostparasite population interactions: I. Regulatory processes. J. Anim. Ecol. 47, 219-247.

Berger, L., et al. (1998). Chytridiomycosis causes amphibian mortality associated wpopulation declines in the rain forests of Australia and Central America. Proceedings of the National Academy of Science of USA 95, 90319036 
Cairns J. (1983) Are single species toxicity tests alone adequate for estimating environmental hazard? Hydrobiologia; 100:47 -57.

Chapman, P.M. (1995). Ecotoxicology and pollution — key issues. Marine Pollution Bulletin 31, 167-77.

Clements WH, Kiffney PM. (1994) Assessing contaminant effects at higher levels of biological organization. Environ Toxicol Chem; 13:357 -359

Daszak, P., L. Berger, A. A. Cunningham, A. D. Hyatt, D. E. Green, and R. Speare. (1999). Emerging infectious diseases and amphibian population declines. Emerging Infectious Diseases 5:735-748

Duursma, E.K., Marchand, M., (1974). Aspects of organic marine pollution. Oceanography and Marine Biology Annual Review 12, 315-431 .Jolles, A.E., Cooper, D.V., Levin, S.A. (2005). Hidden effects of chronic tuberculosis in African buffalo. Ecology 86, 2358-2364.

Jokela, J., Taskinen, J., Mutikainen, P., Kopp, K. (2005). Virulence of parasites in hosts under environmental stress: experiments with anoxia and starvation. Oikos 108, 156-164

Lafferty, K.D., Holt, R.D. (2003). How should environmental stress affect the population dynamics of disease? Ecol. Lett. 6, 654-664.

Long ER, Macdonald D, Smith SL, Calder FD. (1995) Incidence of adverse biological effects within ranges of chemical concentrations in marine and estuarine sediments. Environ Manaegment; 19:81 -97.

Nichols,D.K., A. P. Pessier, and J. E. Longcore. (1998). Cutaneous chytridiomycosis: an emerging disease? Proceedings of the American Association of Zoo Veterinarians 1998, 269-271.

Poteet, M.F. (2006). Shifting roles of abiotic and biotic regulation of a multihost

parasite following disturbance. In: Collinge, S.K., Ray, C. (Eds.), Disease Ecology. Oxford University Press, New York, pp. 135-153.

Pounds, A. J., et al. (2006). Widespread amphibian extinctions from epidemic disease driven by global warming. Nature 439, 161-167.

Rohr, J. R., T. R. Raffel, J. M. Romansic, H. McCallum, and P. J. Hudson. (2008). Evaluating the links between climate, disease spread, and amphibian declines. Proceedings of the National Academy of Science of USA 105, 17436-17441

Rome, L.C., Stevens, E.D., John-Alder, H.B. (1992). The influence of temperature and thermal acclimatation on physiological function. In: Ferder, M.E., Burggren, W.M. (Eds.), Environmental Physiology of the Amphibians. The Univ. Chicago Press, Chicago, pp. 183-205.

.Sala, O., F. Chapin III, J. Armesto, E. Berlow, J. Bloomfield, R. Dirzo, E. Huber-Sanwald, L. Huenneke, R. Jackson, and A. Kinzig. (2000). Global biodiversity scenarios for the year 2100. Science 287, 1770-1774. 
Stuart, S.N., Chanson, J.S., Cox, N.A., Young, B.E., Rodrigues, A.S.L., Fischman, D.L., Waller, R.W. (2004). Status and trends of amphibian declines and extinctions worldwide. Science 306, 1783-1786

Wilson, R.S., Franklin, C.E. (1999). Thermal acclimation of locomotor performance in tadpoles of the frog Limnodynastes peronii. J. Comp. Physiol. B 169, 445-451

Wilson, R.S., Franklin, C.E. (2000). Inability of adult Limnodynastes peronii (Amphibia: Anura) to thermally acclimate locomotor performance. Comp. Biochem. Physiol. A 127, 21-28. 